\title{
Correction: Prelude to a panzootic: Gene flow and immunogenetic variation in northern little brown myotis vulnerable to bat white-nose syndrome
}

\begin{abstract}
Christina M. Davy ${ }^{\text {abc } * \text {, Michael E. Donaldson }}{ }^{\text {cd }}$, Yessica Rico ${ }^{a e}$, Cori L. Lausen ${ }^{f}$, Kathleen Dogantzis ${ }^{d}$, Kyle Ritchie $^{\mathrm{d}}$, Craig K.R. Willis ${ }^{\mathrm{b}}$, Douglas W. Burles ${ }^{\mathrm{g}}$, Thomas S. Jung ${ }^{\mathrm{h}}$, Scott McBurney', Allysia Park ${ }^{\mathrm{i}}$, Donald F. McAlpine ${ }^{j}$, Karen J. Vanderwolf ${ }^{j \mathrm{k}}$, and Christopher J. Kyle ${ }^{\text {acd }}$

${ }^{a}$ Wildlife Research and Monitoring Section, Ontario Ministry of Natural Resources and Forestry, 2140 East Bank Drive, Peterborough, ON K9J 7B8, Canada; ${ }^{b}$ Department of Biology, University of Winnipeg, 515 Portage Avenue, Winnipeg, MB R3B 2E9, Canada; ${ }^{c}$ Environmental and Life Sciences Graduate Program, Trent University, Peterborough, ON K9J 7B8, Canada; ${ }^{\mathrm{d}}$ Forensic Science Department, Trent University, 2140 East Bank Drive, Peterborough, ON K9J 7B8, Canada; ${ }^{\mathrm{e} C a t e d r a ́ t i c o ~ C O N A C Y T, ~}$ Instituto de Ecología A.C., Centro Regional del Bajío, Avenida Lázaro Cárdenas 253, Pátzcuaro, Michoacán 61600, México; ${ }^{\mathrm{f}}$ Wildlife Conservation Society Canada, P.O. Box 606, Kaslo, BC V0G 1M0, Canada; ${ }^{\mathrm{g}}$ Gwaii Haanas National Park Reserve/Haida Heritage Site, P.O. Box 37, Queen Charlotte City, BC V0T 1S0,

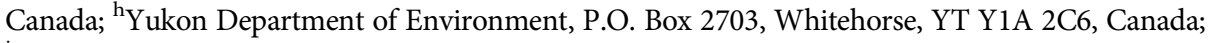
${ }^{\mathrm{i}}$ Canadian Wildlife Health Cooperative, Atlantic Region, Atlantic Veterinary College, University of Prince Edward Island, 550 University Avenue, Charlottetown, PEI C1A 4P3, Canada; ${ }^{j}$ New Brunswick Museum, 277 Douglas Avenue, Saint John, NB E2K 1E5, Canada; ${ }^{k}$ Canadian Wildlife Federation, 350 Promenade Michael Cowpland Drive, Kanata, ON K2M 2G4, Canada

*christina.davy@ontario.ca
\end{abstract}

Re: Davy CM, Donaldson ME, Rico Y, Lausen CL, Dogantzis K, Ritchie K, Willis CKR, Burles DW, Jung TS, McBurney S, Park A, McAlpine DF, Vanderwolf KJ, and Kyle CJ. 2017. Prelude to a panzootic: Gene flow and immunogenetic variation in northern little brown myotis vulnerable to bat white-nose syndrome. FACETS 2: 690-714. doi:10.1139/facets-2017-0022

In the originally published version of the article the middle initials of two of the authors were incorrect in the list of authors, in the citation, and in the author contributions section.

The corrected information is shown here:

Donald F. McAlpine / DFM

Karen J. Vanderwolf / KJV

The originally published information is also included here for reference:

Donald J. McAlpine / DJM

Karen F. Vanderwolf / KFV

The article has been corrected accordingly. 